\title{
Система фінансово-економічного забезпечення енергозберігаючих заходів в Україні та ЄС
}

\begin{abstract}
Фінансово-економічне забезпечення енергозберігаючих заходів є досить важливою складовою для подальшого розвитку Украӥни. Загальновідомо, щчо нинішній стан енергозбереження як $в$ промисловості, бюджетній сфері, так і в домогосподарствах потребують негайної модернізації та оновлення. Рівень енерговитрат Украӥни - найвищий серед усіх краӥн Свропи. Так, дійсно, Украӥна зробила за останній час великі кроки у сторону зменшення енерговитрат, але иього недостатньо. Ï̈ рейтинг у 2018 р. істотно покращився. На сьогодні урядом Украӥни на законодавчому рівні суттєво врегульовано низку питань. Виокремлено усі технічні аспекти енергозберігаючих заходів, але залишилося найбільш вагоме питання - це фінансове забезпечення иих заходів. Саме тому в статті розглянуто європейську практику застосування фінансових механізмів енергозберігаючих заходів. Згруповано досвід краӥн ЄС щзодо застосування інструментів фінансування енергоефективності. Це дало змогу окреслити традиційні та нетрадиційні групи фінансування енергозбереження в Україні. Зазначено, щзо в Україні зазвичай використовуються традииійні фінансові механізми енергозберігаючих проектів. Існує практика застосування і міжнародних фінансових інститутів. Останні реалізують свою діяльність з бюджетними установам або підприємствами. У найгіршому стані опинилися звичайні домогосподарства. Зазвичай вони не в змозі використовувати банківські кредити для енергозберігаючих заходів. Тому в роботі розглянуто нетрадиційні механізми фінансування енергоефективних заходів, такі як ЕСКО, Р2Р, краудфаундінг та револьверний фонд.
\end{abstract}

Ключові слова: енергоефективність; енергозбереження; заходи; фінансово-економічні механізми; інструменти фінансування.

Актуальність теми. У 2015 р. було підписано Паризьку угоду, яка ратифікована і набрала чинності. Ключові країни світу - США, держави СС, Китай, Індія - визнали необхідність поступової відмови від викопного палива та повного переходу на відновлювану енергетику до 2050 р. Згідно 3 висновками цього Світового енергетичного форуму майбутнє світової енергетики - за децентралізованими джерелами енергії, «розумними» мережами та «розумним» транспортом. Світ переступає поріг нової технічної революції, у центрі якої - сонячна та вітрова енергетика, інноваційні технології зберігання та розподілу енергії.

В умовах європейської інтеграції України, належної уваги заслуговує досвід ЄС у питаннях формування державної політики енергозбереження та енергоефективності й механізмів ії реалізації. Саме досвід у сфері енергоефективності ЄС становить для України найбільший інтерес. Це пов'язано з тим, що у нашої країни з СС налагоджено тісні торговельні відносини, а обсяг товарообігу з СС (якщо не враховувати нашу досі актуальну енергетичну залежність від Росії) перевищує обсяг товарообігу України з іншими країнами та регіонами світу.

Аналіз останніх досліджень та публікації, на які спирається автор. Питання фінансово-економічного забезпечення енергозберігаючих проектів як у європейських країнах, так і в Україні висвітлено у роботах вітчизняних і зарубіжних вчених: А.Ю. Данілова, С.М. Бевза, Б.І. Бондаренко, С.П. Денисюка, О.І. ЦапкоПіддубна та інших. Разом 3 тим, на сьогодні відсутній фінансово-економічний механізм забезпечення енергоефективних заходів, особливо для домогосподарств, який би відповідав вимогам та викликам сьогодення, поєднував українські реалії та можливості з кращими європейськими практиками.

Метою статті є дослідження фінансово-економічних механізмів забезпечення енергоефективних заходів в європейських країнах та Україні.

Викладення основного матеріалу. На початку XX ст. головні напрями політики енергоефективності в Свропі були пов'язані з впровадженням у всіх інституціональних секторах енергозберігаючих технологій i обладнання, активізацією використання альтернативних джерел енергії, скороченням технологічних i комерційних втрат під час виробництва, транспортування та споживання енергоносіїв [1, с. 14].

Посилення уваги країн ЄС (насамперед Німеччини, Італії, Франції, Швеції, Данії та Польщі) до вирішення завдань із подальшого підвищення ефективності використання ПЕР обумовлене такими причинами: нинішній геоекономічний формат взаємодії країн вимагає постійного посилення їх конкурентних позицій у глобалізованому економічному просторі; триваюче погіршення цінової кон'юнктури на європейських енергетичних ринках; наявність в ЄС резервів для підвищення енергоефективності у його внутрішньому енергетичному секторі. Політику ЄС у сфері енергоефективності вигідно вирізняє наявність міцного програмного та законодавчо-нормативного підгрунтя; застосування низки адекватних інструментів та ініціатив щодо реалізації політики, функціонування дієвої системи моніторингу та контролю за їх застосуванням; комплексне поєднання 3 іншими напрямами державного регулювання, насамперед -3 екологічною та економічною політикою [2-4]. 
Проведений 22 травня 2013 р. саміт Свропейської ради на політичному рівні констатував зміну пріоритетів енергетичної політики ЄС: замість «сталої енергії» на перший план виходить «конкурентоспроможна енергія». Основним пунктом порядку денного саміту було питання про високі ціни на енергоносії та їх вплив на конкурентоспроможність економіки СС [5].

Європейське законодавство у сфері енергоефективності ухвалювали на основі десятиліть успіхів та помилок багатьох країн. Впровадження заходів 3 енергоефективності починалося 3 обов'язкового обліку споживання електрики, газу, тепла та води, 3 перевірки відповідності будівель мінімальним вимогам енергоефективності та державної допомоги при проведенні термічної модернізації [6].

30 листопада 2016 р. Сврокомісія заявила про курс на розбудову децентралізованої відновлюваної енергетики як про стратегічний пріоритет. На це спрямований новий комплекс регуляторних заходів та політик, об’єднаних у програму «Чиста енергія для всіх європейців» [7].

Також слід зазначити, що на сьогодні для кожної країни Всесвітня енергетична рада (World Energy Council - WEC) щорічно розраховує індекс енергетичної стійкості. Присвоюється індекс на основі проведеного порівняльного аналізу енергетичної ситуації в певній країні, що базується на трьох показниках: «енергетична безпека» (energy security), «енергетична ємність» (energy equity), «екологічна стійкість» (environmental sustainability), 3 урахуванням збалансованого підходу між відповідними показниками. Цей індекс $\epsilon$ найголовнішим у визначенні рівня енергоефективності будь-якої країни.

Залежно від успіхів у кожному напрямі, країні присвоюється рейтинг від А до D в алфавітному порядку, де кожній літері присвоюється шкала від 0 до 10:

- А - найвищий результат, відповідає шкала від 8,01 до 10,00;

- В - середній результат, відповідає шкала від 5,01 до 8,00;

- C - нижче середнього, відповідає шкала від 2,51 до 5,00;

- D - найнижчий, незадовільний результат, відповідає шкала від 0 до 2,5.

Рейтинг України у 2018 р. (АВС) показано у таблиці 1.

Таблиия 1

Індекс енергетичної стійкості Украӥни (2016-2018 рр.)

\begin{tabular}{|l|c|c|c|}
\hline \multirow{2}{*}{\multicolumn{1}{|c|}{ Показник }} & \multicolumn{3}{c|}{ Рейтинг } \\
\cline { 2 - 4 } & $2016 \mathrm{p}$. & $2017 \mathrm{p}$. & $2018 \mathrm{p}$. \\
\hline Енергетична безпека (energy security) & $\mathrm{A}$ & $\mathrm{A}$ & $\mathrm{A}$ \\
\hline Енергетична ємність (energy equity) & $\mathrm{B}$ & $\mathrm{B}$ & $\mathrm{B}$ \\
\hline Екологічна стійкість (environmental sustainability) & $\mathrm{D}$ & $\mathrm{D}$ & $\mathrm{C}$ \\
\hline Загальна оцінка/загальна кількість країн & $63 / 125$ & $48 / 125$ & $57 / 125$ \\
\hline
\end{tabular}

Відповідно до розрахунків і порівнянь, Україна у 2016-2018 рр. піднялася на 47 позицій. У 2016 р. зайняла 63 місце серед 125 країн світу, у 2017 р. також мала тенденцію до покращення своєї позиції на 15 пунктів, але у 2018 р. втратила їі на 9 пунктів.

За даними проведеного аналізу WEC, причиною погіршення показника енергетичної безпеки в Україні є: політична нестабільність; низький відсоток відновлювальної енергетики у загальному обсязі; енергетична залежність від імпортованих енергоносіїв, неефективне використання ПЕР.

Низький рівень показників енергетичної ємності та екологічної стійкості більшою мірою зумовлено високою енергоємністю ВВП та відсутністю чітких кроків щодо зменшення негативного впливу на навколишнє середовище, що є наслідком неефективної політики держави в енергетичному секторі [8].

Згідно з цим самим рейтингом, найкращий результат у 2018 р. мають такі країни: Швейцарія, Швеція, Норвегія, Великобританія, Австрія, Данія, Канада, Франція, Фінляндія, Нідерланди та США.

Світовий досвід показує, що дієві заходи в напрямі енергоефективності можуть скоротити зростання національного попиту на ПЕР, що дозволить знизити їх імпорт та, відповідно, вирішити енергетичні проблеми країн з перехідною економікою. Водночас правильно розроблена енергетична стратегія країни, дієві проекти міжнародного співробітництва в сфері підвищення енергоефективності сприятимуть зростанню енергетичної ефективності, економічному розвитку, екологічній та національній безпеці країни. В індустріально-розвинених країнах, на відміну від колишньої орієнтації на великомасштабне нарощування виробництва енергетичних ресурсів, головним пріоритетом енергетичної стратегії $€$ підвищення рівня енергоефективності.

У багатьох країнах розроблено національні цільові програми економії використання паливно-енергетичних ресурсів, які містять великий комплекс заходів із вдосконалення структури споживання енергоносіїв, розвитку матеріально-технічної бази, більш повного вилучення корисних компонентів, збору та використання вторинної сировини, контролю та обліку енергоспоживання.

Так у країнах Західної Свропи, де переважають ринкові відносини, в питаннях вдосконалення енергоефективності, як правило, намагаються уникати правового регулювання, надаючи перевагу інформаційним програмам та програмам, що підвищують рівень технічної обізнаності. Основний принцип, якого вони дотримуються - чим вище енергетична інтенсивність, тим менше нормативного регулювання у цій сфері. Наприклад, у промисловості ринок сам змусить підвищувати енергоефективність, знижувати 
енергоємність виробленої продукції 3 метою підвищення іiі конкурентоспроможності. Окрім того, при економічному регулюванні енергоефективності часто застосовують примусові заходи, які містять законодавчо закріплені норми та ініціативи, які впроваджуються «зверху». Ці рішення найбільш популярні в країнах Свропи, де законослухняне населення і виробники підтримують обов'язкові державні програми.

В іншому випадку, часто впроваджуються стимулюючі заходи, які безпосередньо впливають на виробника. В країнах, які активно використовують цей метод, в хід ідуть інструменти фінансового стимулювання, а також PR-інструменти. Прорахувати економічну ефективність подібних рішень складніше, ніж у випадку 3 примусовими заходами [9].

Під час проведення аналізу згруповано всі фінансові механізми в сфері енергоефективності. Так до найбільш розповсюджених належать такі: кредитне фінансування та схеми часткових гарантій (проводиться комерційними банковими установами або спеціалізованими агенціями, фондами револьверного фінансування); використання енергосервісних компаній (ЕСКО, це такі компанії, які використовують контракти гарантування результатів енергозаощаджень для здійснення інвестицій на об'єктах комунальної чи приватної власності); використання компаніями теплозабезпечення схем Demand-Side-Management (в програмах DSM компанії 3 постачання тепла організують впровадження енергоефективних проектів у споживачів, забезпечуючи фінансування, технічні рішення та контрактні відносини зі споживачами); інші види фінансування (у формах публічно-приватного партнерства, грантів або Альянсів глобального розвитку, фінансування у форматі Кіотського протоколу).

Також слід зазначити, що, з огляду на світовий досвід, Міжнародне енергетичне агентство (International Energy Agency) виокремлює такі механізми політики енергоефективності на рівні держав: цінові; регулятивні та контролюючі; фінансового та фіскального стимулювання; промоуційні (інформаційні) механізми; технологічного, комерційного та фінансового розвитку [10, с. 300-311]. У таблиці 2 згруповано механізми (ціновий, регулятивний, контролюючий, інформаційний та мотиваційний) управління енергоефективністю на основі проведеного аналізу кращого досвіду європейських країн.

Таблиця 2

Систематизація елементів політики енергоефективності

\begin{tabular}{|c|c|c|c|c|c|}
\hline \multirow{2}{*}{ Країна } & \multicolumn{5}{|c|}{ Елементи політики енергоефективності } \\
\cline { 2 - 6 } & ціновий & регулятивний & контролюючий & інформаційний & мотиваційний \\
\hline Норвегія & + & + & + & & + \\
\hline Швеція & & + & & + & + \\
\hline Німеччина & & & & + & + \\
\hline Данія & & & + & + & + \\
\hline Польща & + & & & + & + \\
\hline Чехія & & & & & + \\
\hline
\end{tabular}

Отримані дані про досвід країн світу в енергоефективності згрупуємо у таблицю для їх порівняння між собою (табл. 3).

Табличя 3

Міжнародний досвід фінансування енергоефективних проектів

\begin{tabular}{|c|c|}
\hline Країна & Досвід \\
\hline Норвегія & $\begin{array}{l}\text { Ïї досвід характеризується як процес забезпечення енергоефективності з урахуванням усіх } \\
\text { аспектів лібералізованих ринків, цільового планування й захисту навколишнього середовища }\end{array}$ \\
\hline Швеція & $\begin{array}{l}\text { Налагоджена чітка система контролю за використанням «Енова СФ» енергоресурсів. } \\
\text { Практикується звільнення терміном на п’ять років від енергетичного податку, надання субсидії } \\
\text { держави для реконструкції старих будівель (заміна котлів, утеплення тощо), спрощено } \\
\text { отримання дозволів на будівництво вітрових електростанцій }\end{array}$ \\
\hline Німеччина & $\begin{array}{l}\text { Виробництво енергії за рахунок використання вугілля й альтернативних джерел енергії. } \\
\text { Використання державних дотацій на стимулювання екологічних альтернативних видів енергії } \\
\text { й видобуток бурого й кам'яного вугілля. Впровадження енергоефективності в Німеччині } \\
\text { фінансується за рахунок банків та великих корпорацій }\end{array}$ \\
\hline Данія & $\begin{array}{l}\text { Законопроект «Зелена трансформація для Данії». Головна мета полягає у стовідсотковому } \\
\text { переході на альтернативні види енергії у сферах електро- і теплопостачання у приватному } \\
\text { секторі, промисловій і транспортній галузях до } 2050 \text { р. }\end{array}$ \\
\hline Польща & $\begin{array}{l}\text { Отримання кредитів від комерційних та державних банків для модернізації житлового фонду } 3 \\
\text { низьким відсотком }(2-10 \%) \text { під гарантію повернення через тарифну політику. Створення } \\
\text { фонду «Теплової реновації та капітального ремонту», який став основним фінансовим донором }\end{array}$ \\
\hline Чехія & $\begin{array}{l}\text { Організовано державну Програму «Зелені заощадження». Створено Державний екологічний } \\
\text { фонд Чехії, який отримує фінансування від міжнародних організацій }\end{array}$ \\
\hline
\end{tabular}


Таким чином, можемо зауважити, що кожна країна для розвитку енергоефективності зробила вагомий внесок. Звернемо увагу i на те, що згідно з висновками європейських фахівців, найбільш надійними інструментами енергозбереження є такі фінансово-економічні регулятори і стимули, як ціни та тарифи, пільгове оподаткування, державна фінансова підтримка. Провідну роль в енергозбереженні відіграє і кваліфікований енергоменеджмент, що креативно працює за умови виконання вимог міжнародних стандартів.

У провідних країнах Свропи на сьогодні існують різні механізми фінансування енергоефективних проектів. У таблиці 4 наведено основні інструменти фінансування енергоефективності.

Табличя 4

Інструменти фінансування енергоефективності (досвід країн СС)

\begin{tabular}{|c|c|c|c|c|c|c|}
\hline Країна & Гранти & $\begin{array}{c}\text { Пільгове } \\
\text { кредиту- } \\
\text { вання } \\
\end{array}$ & $\begin{array}{l}\text { Подат- } \\
\text { кові } \\
\text { пільги } \\
\end{array}$ & $\begin{array}{c}\text { Продаж квот за } \\
\text { механізмом Кіотсь- } \\
\text { кого протоколу }\end{array}$ & ECKO & $\begin{array}{l}\text { Європейські } \\
\text { структурні та } \\
\text { спільні фонди }\end{array}$ \\
\hline Австрія & 4 & + & + & & + & \\
\hline Бельгія & + & + & + & & + & \\
\hline Болгарія & + & + & & & + & + \\
\hline Кіпр & + & + & & & & \\
\hline Чехія & + & + & + & + & + & + \\
\hline Данія & + & & + & & & \\
\hline Естонія & + & + & + & + & & + \\
\hline Фінляндія & + & + & + & & & \\
\hline Франція & + & + & + & & + & + \\
\hline Німеччина & + & + & + & & + & \\
\hline Греція & + & + & + & & & + \\
\hline Угорщина & + & + & & + & & + \\
\hline Ірландія & + & & + & & + & \\
\hline Італія & + & + & + & & + & + \\
\hline Латвія & + & + & + & + & + & + \\
\hline Литва & + & + & + & + & + & + \\
\hline Люксембург & + & + & + & & & \\
\hline Мальта & + & + & + & & + & + \\
\hline Нідерланди & + & + & + & & + & \\
\hline Польща & + & + & & + & + & + \\
\hline Португалія & + & & & & + & + \\
\hline Румунія & + & + & + & & + & + \\
\hline Словаччина & + & + & + & & & + \\
\hline Словенія & + & + & + & & + & + \\
\hline Іспанія & $1+$ & + & + & & + & \\
\hline Швеція & \pm & & + & + & + & \\
\hline
\end{tabular}

Гранти/субсидії в енергоефективність є найдоступнішим та найпоширенішим інструментом фінансування енергоефективності в країнах ЄC [11]

Як зрозуміло з даних таблиці 4, найпоширенішим джерелом фінансування енергоефективних проектів $€$ гранти та субсидії.

Якщо говорити про Україну, то на сьогодні також використовують такі традиційні джерела фінансування, як донорські організації, місцеві бюджети, жителі громади та бізнес.

Донорські організації:

1. Кредитні кошти через українські банки.

2. Безповоротні кошти на проведення підготовчих робіт (бізнес-план, енергоаудит, консультації тощо).

3. Безповоротні (грантові) кошти на реалізацію окремих проектів. 
Найбільшими постачальниками кредитних ресурсів на енергозберігаючі проекти є міжнародні фінансові інститути. Міжнародне фінансове і технічне співробітництво 3 державами та міжнародними організаціями $\epsilon$ потужним джерелом та ефективним інструментом економічного розвитку України.

Україна прагне ефективно використовувати весь потенціал такого співробітництва на основі взаєморозуміння та рівноправного партнерства, вироблення спільних підходів щодо пріоритетів співробітництва, спільної відповідальності та підзвітності за результати наданої допомоги, забезпечення їі ефективного використання для розв'язання найгостріших соціальних і економічних проблем.

Одними з таких потужних міжнародних організацій є ЄС (Свропейський Союз: партнерство країн Східної Європи 3 охорони навколишнього середовища та енергозбереження («Е5Р»), ЄБРР (Європейський банк реконструкції і Розвитку), (СІБ) Свропейський інвестиційний банк, (ГЕФ) Глобальний екологічний фонд (до якого входять СБРР, ПРООН, ЮНЕП, ЮНІДО, МБРР), (НЕФКО) Північна екологічна фінансова корпорація, (ПIБ) Північний інвестиційний банк, (GCPF) Глобальний фонд кліматичного партнерства, (DIGH) Фонд «Голландські міжнародні гарантії для житлового фонду», Група Світового банку - (Субнаціональні фінанси від МФК та МБРP), (USAD) Світовий банк, Агентство США 3 міжнародного розвитку, (KfW) Німецький державний банк розвитку, (GIZ) Німецьке товариство технічного співробітництва та інші.

Також варто зазначити, що у 2017 р. було прийнято проект Закону «Про Фонд енергоефективності», метою якого є підтримка ініціатив щодо енергоефективності, впровадження інструментів стимулювання і підтримки здійснення заходів із забезпечення енергетичної ефективності будівель та енергозбереження переважно в житловому секторі з урахуванням національних планів щодо енергетичної ефективності [12]. Створення Фонду енергоефективності дасть змогу Україні отримати від Європейського Союзу кошти для вирішення проблеми енергозбереження. Джерелами наповнення Фонду повинні стати кошти з державного бюджету України та донорів.

Окремої уваги заслуговує програма Кабінету Міністрів України «Теплі кредити». Згідно 3 нею обсяг коштів, які спрямовані на видачу населенню кредитів для придбання енергоефективних матеріалів i обладнання, у 2015 р. складав 1,57 млрд грн, у 2016 р. - 900 млн грн, у 2017 р. - 400 млн грн, у 2018 р. 400 млн грн, у 2019 р. - 400 млн грн, у 2020 р. передбачено 400 млн грн [13].

Відшкодування, які надаються учасникам цієї програми, становлять:

- 20 \% суми кредиту (але не більше 12 тис. грн) на придбання негазових/неелектричних котлів для фізичних осіб;

- 35 \% суми кредиту (але не більше 14 тис. грн) на придбання енергоефективного обладнання/матеріалів для фізичних осіб;

- $40 \%$ суми кредиту (але не більше 14 тис. грн в розрахунку на одну квартиру) на придбання енергоефективних матеріалів та обладнання для ОСББ (окрім домогосподарств, які отримують субсидіі);

- $70 \%$ (але не більше 14 тис. грн в розрахунку на одну квартиру) на придбання енергоефективних матеріалів та обладнання для ОСББ (тільки для домогосподарств, які отримують субсидіï) [14].

Видачу таких кредитів задля підтримки енергозбереження здійснювали такі банки-агенти, як «Ощадбанк» (програма «Ощадний дім»), «Укргазбанк» (програма «Тепла оселя»), «Укрексімбанк» та «Приватбанк».

Наступна група джерел фінансування енергоефективних проектів є нетрадиційною. До неї належать такі джерела, як ЕСКО-механізм, краудфаундінг, Р2Р, револьверний фонд.

Фінансування енергоефективних проектів ЕСКО-компаніями. ЕСКО - це енергосервісна компанія, яка виконує роботи із впровадження енергоефективних заходів (наприклад, утеплення фасадів, заміна вікон та дверей на енергоефективні, модернізація системи опалення, встановлення ІТП тощо). Завдяки цим заходам замовник починає економити ресурси та, відповідно, гроші, частину яких отримує ЕСКО як плату за свої послуги та повертає вкладені інвестиції. Також, завдяки нещодавнім змінам у законодавстві стала можливою реалізація так званого принципу «first out», коли всі заощаджені кошти спрямовуються на оплату послуг ЕСКО. В такому разі термін енергосервісного договору скорочується [15].

Наступне нетрадиційне джерело фінансування енергоефективних проектів це краудфандінг (від англ. crowdfunding: «crowd» - натовп, «funding» - фінансування) - це співпраця людей, які добровільно об’єднують свої гроші або інші ресурси разом, як правило, через Інтернет, щоб підтримати зусилля інших людей або організацій. Фінансування за схемою краудфандінгу може виконувати різні функції - створення безкоштовного вільного програмного забезпечення, фінансування стартап компаній та малого бізнесу тощо. Використання краудфандінгу передбачає для початку збір коштів. Обов'язково має бути задекларована мета, визначено суму необхідних коштів для iї досягнення, а кошторис усіх витрат і процес збору мають бути доступні та відкриті для суспільства.

Основна ідея його роботи - це:

- як правило, збір коштів відбувається серед інтернет-користувачів на спеціальних вебсайтах (краудфандінгових платформах);

- $\quad$ платформа бере на себе забезпечення багатьох аспектів, у тому числі фінансових і юридичних, а також допомагає в просуванні та полегшує взаємодію всіх учасників;

- 3 платформою укладається договір;

- платформі виплачується процент від суми (5-10 \%) [16]. 
Наступний вид фінансування - це кредитування Р2P. Р2Р розшифровують як peer-to-peer aбо person-to person кредитування, що означає кредитування рівних або людини людині, іншими словами це кредитування фізичною особою фізичної особи.

При Р2Р-кредитуванні в кредитні взаємини вступають рівноправні сторони і укладають договір один 3 одним 3 приводу позикової вартості за допомогою посередника - мікрофінансової організації чи банку. Даний вид діяльності, як правило, ведеться в електронній формі та являє собою форму мікрокредитування, в якій видача й отримання позик фізичними особами здійснюється безпосередньо, без залучення банків.

Традиційним майданчиком для надання Р2Р-кредитів $\epsilon$ інтернет. Це може бути як самостійний сайт (наприклад, сервіси Fingooroo, Loanberry, Webtransfer), так і сервіс у межах існуючого $з$ іншою метою сайта (наприклад, біржа кредитів на WebMoney, Сервіс вигідних вкладень) [17, с. 94].

Р2Р-інвестування не слід плутати 3 Р2Р-кредитуванням, оскільки в цьому випадку відбувається безпосередня взаємодія з позичальником.

Р2Р-інвестування - це практика інвестування грошових коштів позичальниками, які мають гарантії, які запитують позику, не вдаючись при цьому до послуг традиційного фінансового посередника, і які інвестору невідомі. Інвестування відбувається онлайн через Р2Р інвестиційну компанію. С індивідуальний інвестор і окремий позичальник. Гарантії (векселі) можуть бути продані як забезпечення i, таким чином, інвестори можуть вийти з інвестицій перш ніж позичальник відшкодує борг.

Сервіс Р2Р-кредитування є платформою, яка об’єднує 3 одного боку кредиторів, а 3 другого позичальників. Платформа не приймає на себе кредитні ризики - всі позики видаються за рахунок коштів кредиторів.

Сервіс проводить скоринг позичальників, надає послуги зі збору простроченої заборгованості і зручної оплати за виданими кредитами.

Процентні ставки або встановлюються кредиторами (позикодавцями), які конкурують за найнижчу ставку в межах зворотного аукціону, або визначаються компанією-посередником за результатами аналізу кредиту позичальника.

Позичальникам, які за результатами оцінки мають більше шансів зазнати дефолту, присвоюються вищі ставки.

Кредитори пом'якшують ризик того, що позичальники не повернуть отримані гроші, вибираючи, кому 3 них можна надати кредит, а також варіюючи свої інвестиції залежно від характеристик позичальника.

Фінансування за рахунок коштів револьверного фонду. Револьверний фонд - це популярний у світі фінансовий інструмент, який дозволяє отримати кошти на різноманітні проекти. На відміну від фінансування 3 місцевих чи державних бюджетів, кошти револьверного фонду значно мобільніші: ними можна розпоряджатися не лише в межах одного фінансового року, а також уникнути додаткових бюрократичних обмежень у вигляді програми фінансування тощо. Револьверний фонд передбачає поворотне надання коштів на реалізацію певних проектів. У випадку, якщо проект, профінансований з револьверного фонду, став дохідним або на ньому вдалося зекономити, ці кошти повертаються до револьверного фонду та використовуються для фінансування наступних заходів [18].

Револьверний фонд може бути як фінансовою інституцією, так і звичайним розрахунковим рахунком у банку. В обох випадках його кошти спрямовуються на підтримку заходів певного напряму діяльності (культура, освіта, енергоефективність тощо). Кошти надаються на певний час, а після повернення використовуються повторно. Таким чином досягається висока ефективність використання грошей.

Револьверний фонд може надавати позики на пільгових умовах для фінансування важливих для власників фонду заходів. Позики фонду можуть надаватися за умови виконання певних критеріїв (проведення енергетичних аудитів, встановлення лічильників, навчання персоналу тощо), втілення яких посилює ефект від кредиту чи навіть перевищує його.

Револьверний фонд може фінансувати заходи у межах місцевого бюджету, галузі, організації або структури. Тоді фонд є окремим цільовим утворенням, кошти якого обліковуються на відокремленому банківському рахунку (іноді віртуальному), з якого і здійснюється цільове фінансування. Часто цей рахунок наповнюється зекономленими в результаті заходів коштами. Досвід використання револьверних фондів у світі свідчить, що це зручний інструмент фінансування енергоефективних заходів, особливо, якщо вдається повертати кошти за рахунок досягнутої економії.

Діяльність револьверного фонду може поширюватися як на усіх потенційних користувачів (державні та комунальні заклади, ОСББ, підприємства та населення), так і на окремі категорії (власників квартир $з$ центральним опаленням у будинках, де такі квартири становлять не більше 10 \%, власників індивідуальних житлових будинків, користувачів велосипедів тощо). Крім того, револьверний фонд може бути створений для фінансування проектів в окремій галузі (вуличне освітлення, теплопостачання, енергоефективність в будівлях тощо).

В Україні не існує спеціального законодавства, яке регулює діяльність «револьверних фондів» в цілому та тих, що працюють у сфері енергоефективності.

За своєю цивільно-правовою природою поворотна фінансова допомога (кошти револьверного фонду) є позикою і не є наслідком одержання прибутку позикодавцем чи будь-якими іншими особами, які надають кошти для позики. Проте у разі надання позики фізичній особі більш ніж на рік, згідно з чинним Податковим 
кодексом України, сума такої позики включається до загального річного оподатковуваного доходу фізичної особи як інші доходи та оподатковується податком на доходи фізичних осіб за ставками 15-20 \%, визначеними п. 167.1 ст. 167 Податкового кодексу України і військовим збором (1,5 \%). При цьому зазначений дохід відображається у графі «Інші доходи» річної податкової декларації про майновий стан і доходи.

При наданні позик, наприклад, ОСББ податкові зобов'язаня не виникають у разі використання позики на обслуговування будинку (поточні та капітальні ремонти, облаштування тощо). Тобто, при використанні всієї суми позики на заходи з утеплення будинку податки платити не доведеться.

У разі створення фонду органом місцевого самоврядування для фінансування заходів на об'єктах, що знаходяться в їхньому відомстві (комунальні підприємства, підпорядковані бюджетні заклади тощо) податкові зобов'язання не виникають ні за яких умов. Фонд буде існувати у вигляді банківського/казначейського рахунка, що необхідно для наявності коштів під фінансування заходів з енергоефективності .

Висновки та перспективи подальших досліджень. Отже, як показав проведений аналіз, в Україні на сьогодні частково використовуються фінансово-економічні механізми забезпечення енергофективних заходів. Практика європейських країн свідчить про те, що використання лише технічних аспектів у вирішенні питань енергоефективності не достатньо. Важливу роль у цьому відіграють фінансові стимули. Здійснити та профінансувати енергоефективні заходи ні бюджетні установи, ні домогосподарства на сьогодні не в змозі. Так міжнародні організації здійснюють фінансування, але зазвичай їхніми об'єктами фінансування є або державні установи, або підприємства чи організації. Домогосподарства в цю категорію не потрапляють. У європейських країнах світу розповсюджена інша практика фінансування енергофективних заходів. В Україні ці механізми, поки що, є нерозповсюдженими, але дуже перспективними та необхідними.

\section{Список використаної літератури:}

1. Професіоналізація та стабілізація енергетичного менеджменту в Україні / Уклад.: С.П. Денисюк, О.В. Коцар, Ю.В. Чернецька // Енергетична ефективність України. Кращі проектні ідеї. - К. : КПІ ім. Ігоря Сікорського, 2016. - 79 с.

2. Грозовский Г. Техническое регулирование энергетической эффективности / Г.Грозовский, В.Попов, Е.Полякова // Стандарты и качество. - 2011. - № 2. - С. 32-36.

3. Енергоефективність та відновлювані джерела енергії / С.М. Бевз та ін. ; під заг. ред. А.К. Шидловського. - К. : Українські енциклопедичні знання, 2007. - 500 с.

4. Енергоефективність як ресурс інноваційного розвитку: Національна доповідь про стан та перспективи реалізації державної політики енергоефективності у 2008 році / С.Ф. Срмілов, В.М. Геєць, Ю.П Ященко та ін. - К. : НАЕР, 2009. - 93 c.

5. Денисюк С.П. ISO 50001: цілі стандарту та перспективи його впровадження в Україні : навч. посіб. / С.П. Денисюк. - К., 2015. - 104 с.

6. Желєзний А. Із грязі в князі. Як влаштувати в Україні енергетичний ренесанс / А.Желєзний [Електронний ресурс]. Режим доступу : http://www.epravda.com.ua/columns/2015/11/18/567765/.

7. Савицький O. Між СРСР і СРСР. Якою буде українська енергетика у 2035 році / О.Савииький [Електронний pecypc]. - Режим доступу: http://www.epravda.com.ua/publications/2017/02/6/619749/.

8. 2015 Energy Trilemma Index: Benchmarking the sustainability of national energy systems. - 2015 [Electronic resource]. Access mode : https://www.worldenergy.org/publications/2015/2015-energy-trilemma-indexbenchmarking-thesustainability-of-national-energy-systems-2/.

9. Данілкова А.Ю. Управління енергоефективністю промислових підприємств : дис. ... канд. екон. наук: спец. 08.00.04 / А.Ю. Данілкова. - Хмельницький, 2016. - 196 с.

10. Цапко-Піддубна О.I. Аналіз механізмів реалізації політики енергоефективності / О.I. Цапко-Піддубна // Науковий вісник Національного лісотехнічного університету України. - 2009. - Вип. 19.11. - С. 300-311.

11. Financing tools reported by Member States in their second National Energy Efficiency Plans (NEEAP), see European Commission [Electronic resource]. - Access mode : https://ec.europa.eu/transparency/regdoc/rep/3/2019/EN/C-2019-6621F1-EN-ANNEX-1-PART-1.PDF.

12. Про фонд енергоефективності : Закон України [Електронний ресурс]. - Режим доступу : https://zakon.rada.gov.ua/laws/show/2095-19.

13. Постанова кабінету Міністрів України № 1056 від 17.10.2011 р. [Електронний ресурс]. - Режим доступу : https://zakon.rada.gov.ua/laws/show/1056-2011-\%D0\%BF.

14. Державне агентство 3 енергоефективності та енергозбереження [Електронний ресурс]. - Режим доступу : http://saee.gov.ua/uk.

15. Sotnyk I.M. Energy efficiency of Ukrainian economy: problems and prospects of achievement with the help of ESCOs / I. M. Sotnyk // Актуальні проблеми економіки. - 2016. - № 1. - С. 192-199 [Електронний ресурс]. - Режим доступу : http://nbuv.gov.ua/UJRN/ape_2016_1_23.

16. Попович Д.В. Краудфандинг як новітній спосіб фінансування в Україні / Д В. Попович, Н.В. Назар, Н.В. Савчин // Молодий вчений. - 2018. - № 10 (2). - С. 873-876.

17. Peer-to-peer кредитування в Україні: перспективи розвитку та виклики для банків / О.В. Крухмаль, О.С. Заєць // Міжнародний науковий журнал «Інтернаука». - № 2 (24), 2 т., 2017. - С. 93-96.

18. Револьверний фонд як інструмент успішного фінансування енергоефективних заходів місцевих громад : посіб. [Електронний ресурс]. - Режим доступу : https://www.euneighbours.eu/sites/default/files/publications/2018 01/20180110\%20CoM\%20DeP\%20Guideline\% 20-\%20RF.pdf. 


\section{References:}

1. Denysjuk, S.P., Kocar, O.V. and Chernec'ka, Ju.V. (2016), "Profesionalizacija ta stabilizacija energetychnogo menedzhmentu v Ukrai'ni», Energetychna efektyvnist' Ukrai'ny. Krashhi proektni idei', KPI im. Igorja Sikors'kogo, 79 p.

2. Grozovskyj, G., Popov, V. and Poljakova, E. (2011), «Tehnicheskoe regulirovanie jenergeticheskoj jeffektivnosti», Standarty $i$ kachestvo, No. 2, pp. 32-36.

3. Bevz, S.M. and al. (2007), «Energoefektyvnist' ta vidnovljuvani dzherela energii'»/ Shydlovs'kogo, A.K. (ed.), Ukrai'ns'ki encyklopedychni znannja, $500 \mathrm{p}$.

4. Jermilov, S.F., Gejec', V.M., Jashhenko, Ju.P., Grygorovs'kyj, V.V., Lir V.E. and al. (2009), Energoefektyvnist' jak resurs innovacijnogo rozvytku, Nacional'na dopovid' pro stan ta perspektyvy realizacii' derzhavnoi' polityky energoefektyvnosti u 2008 roci , NAER, 93 p.

5. Denysjuk, S.P. (2015), ISO 50001: cili standartu ta perspektyvy jogo vprovadzhennja v Ukrai'ni, navch. posib, K., 104 p.

6. Zheljeznyj, A. Iz grjazi $\mathrm{v}$ knjazi. Jak vlashtuvaty $\mathrm{v}$ Ukrai'ni energetychnyj renessans, [Online], available at: http://www.epravda.com.ua/columns/2015/11/18/567765/

7. Savyc'kyj, O. Mizh SRSR i SRSR. Jakoju bude ukrai'ns'ka energetyka u 2035 roci, [Online], available at: http://shshsh.epravda.com.ua/publications/2017/02/6/619749/

8. 2015 Energy Trilemma Index: Benchmarking the sustainability of national energy systems, [Online], available at: https://www.worldenergy.org/publications/2015/2015-energy-trilemma-indexbenchmarking-the-sustainability-of-nationalenergy-systems-2/

9. Danilkova, A.Ju. (2016), Upravlinnja energoefektyvnistju promyslovyh pidpryjemstv, Diss. of. k.e.n., spec 08.00.04, Hmel'nyc'kyj, 196 p.

10. Capko-Piddubna, O. I. (2009), Analiz mehanizmiv realizacii' polityky energoefektyvnosti, Naukovyj visnyk Nacional'nogo lisotehnichnogo universytetu Ukrai'ny, Issue 19.11., pp. 300-311.

11. Financing tools reported by Member States in their second National Energy Efficiency Plans (NEEAP), see European Commission, [Online], available at: https://ec.europa.eu/transparency/regdoc/rep/3/2019/EN/C-2019-6621-F1-ENANNEX-1-PART-1.PDF

12. Pro fond energoefektyvnosti, Zakon Ukrai'ny, [Online], available at: https://zakon.rada.gov.ua/laws/show/2095-19

13. Kabinet Ministriv Ukrai'ny (2011), Postanova kabinetu Ministriv Ukrai'ny № 1056 vid 17.10, [Online], available at: https://zakon.rada.gov.ua/laws/show/1056-2011-\%D0\%BF

14. Derzhavne agentstvo z energoefektyvnosti ta energozberezhennja, [Online], available at: http://saee.gov.ua/uk

15. Sotnyk I.M. (2016), «Energy efficiency of Ukrainian economy: problems and prospects of achievement with the help of ESCOs», Aktual'ni problemy ekonomiky, No. 1., pp. 192-199, [Online], available at: http://nbuv.gov.ua/UJRN/ape_2016_1_23

16. Popovych, D.V. (2018), Kraudfandyng jak novitnij sposib finansuvannja v Ukrai'ni, Molodyj vchenyj, No. 10 (2), pp. $873-876$.

17. Kruhmal', O.V. and Zajec', O. S. (2017), Peer-to-peer kredytuvannja v Ukrai'ni: perspektyvy rozvytku ta vyklyky dlja bankiv, Mizhnarodnyj naukovyj zhurnal «Internauka», No. 2 (24), Vol. 2, pp. 93-96.

18. Revol'vernyj fond jak instrument uspishnogo finansuvannja energoefektyvnyh zahodiv miscevyh gromad, posibnyk, [Online], available at: https://www.euneighbours.eu/sites/default/files/publications/201801/20180110\%20CoM\%20DeP\%20Guideline\% 20-\%20RF.pdf

Ця стаття виконана в рамках участі в програмі ERASMUS+ навчального модуля Жан Моне 599740-EPP-1-2018-1-UAEPPJMO-MODULE: THE CHALLENGES OF ENERGY EFFICIENCY: COOPERATION OF UKRAINE WITH THE EU, що мa€ за мету впровадження європейських практик управління енергоефективністю підприємств України, розробку рекомендацій 3 адаптації законодавства України до стандартів СС, формування пропозицій для поглиблення енергетичного співробітництва України та ЄС та апробування європейського досвіду виховання культури енергоспоживання для популяризації енергоощадливості.

Скриль Віталія Вячеславівна - кандидат економічних наук, доцент, доцент кафедри фінансів, банківського бізнесу та оподаткування Національного університету «Полтавська політехніка імені Юрія Кондратюка».

Наукові інтереси:

- фінансові аспекти енергозбереження та енергоефективності;

- формування та реалізація потенціалу енергоефективності;

- забезпечення економічної безпеки держави, регіону, підприємств.

E-mail skrilvv3333@gmail.com.

https://orcid.org/0000-0003-4064-8146. 